\title{
下肢急性動脈閉塞症の再灌流障害における白血球の関与
}

\author{
一急性動脈閉塞症の実験的検討一
}

梅 澤 久 輝

\begin{abstract}
イヌ急性動脈閉塞再灌流障害モデルを作製し，白血球除去フィルター群と白血球活性化物質である Leukotrien B4（以下 LTB4）の拮抗物質の投与群における再灌流時の白血球の関与を明らかにする 目的で実験を行った。雑種成犬 28 頭の腎動脈下腹部大動脈を結紮し，12 時間後に血流を再開した。 血流再開直前に白血球除去フィルターを使用した群（8 頭）と再灌流直前に LTB4 拮抗物質を投与し た群（8頭）およびコントロール群（12 頭）を作製し，経時的にCPK，イヌ-Myoglobin. GOT を 測定して比較検討した. フィルター群, LTB4 投与群ともに各測定項目はコントロール群と比して低 值を示し，再灌流障害が軽減されるものと考えられた．以上の結果より白血球除去や LTB4 の抑制 により再灌流障害が軽減されたものと推察され，本症の組織障害増大に白血球が関与していることの 証明であると思われた。 日心外会誌 26 巻 3 号：141-149（1997）
\end{abstract}

Keywords : 急性動脈閉塞症, 再灌流障害, 白血球, MNMS

\section{The Role of Leukocytes in Reperfusion Injury Following Acute Arterial Occlusion of the Lower Extremities}

Hisaki Umezawa (The Second Department of Surgery, Nihon University School of Medicine, Tokyo, Japan)

Purpose. To determine the involvement of leukocytes in reperfusion injury following acute arterial occlusion of the lower extremities, the effect of leukocyte removal filters or leukotrien B4 (LTB4) antagonist was investigated using a canine acute arterial occlusion model. Methods. Twenty-eight mongrel dogs, weighing 15 to $20 \mathrm{~kg}$, underwent temporal occlusion of the infrarenal aorta and lumbar arteries followed by release of occlusion 12 hours later. Experimental groups consisted of the three following groups: Group I $(n=12$; control), dogs without any treatment ; Group II $(n=8)$, dogs treated with leukocyte removal filters from the onset of reperfusion until one hour after reperfusion; and Group III $(n=8)$, dogs pretreated with LTB4 antagonist immediately before reperfusion. Serum myoglobin, CPK, and GOT were measured and compared among the three groups. Results. Values of serum myoglobin, CPK, and GOT, were significantly elevated after reperfusion in Group I as compared to those before reperfusion. However, increase in these values was significantly elevated after reperfusion in Group I as compared to those before reperfusion. However, increase in these values was significantly attenuated in Group II and Group III as compared to Group I. Conclusions. These data suggested leukocyte depletion injury following acute arterial occlusion of the lower extremities. Leukocytes appear to play a significant role in this type of reperfusion injury. Jpn. J. Cardiovasc. Surg. 26 : 141-149 (1997)

急性動脈閉塞症に対する治療の原則は早期の血 栓，塞栓除去術による血行再建であり，多くの症 例では局所的にも全身的にも障害を残さず回復 するが，その一方，下肢虚血再灌流後に

\footnotetext{
1996 年 5 月 7 日受付, 1996 年 10 月 15 日採用

日本大学第 2 外科 $\overline{7} 173$ 東京都板橋区大谷口上町 30-1

本論文の要旨は, 第 25 回日本心臟血管外科学会学術総会（1995 年 2 月, 横浜), 第 95 回日本外科学会総会ワークショップ (1995 年 4 月, 名古屋) に扔いて発表した。第 1 回リムサルべ ージ研究会賞（1996 年 6 月, 札幌) 受賞.
}

Myonephropathic-metabolic syndrome（以下 MNMS）に代表される多臓器障害を引き起こす 症例もあり ${ }^{1 \sim 3)}$ ，一度本症を合併すれば致命率が 高く,いまだに解決されていない重篤な合併症の 一つである．本症においては，その病態や治療に 関して数多くの報告 ${ }^{3 \sim 7)}$ がなされているにもかか わらず，その発生機序や病態の詳細は不明な点が 多い. 近年, 白血球動態やその関連物質の研究が 進み, 各種炎症性疾患や再灌流後の障害組織にお 
ける白血球の関与について多くの知見が報告され ている ${ }^{814)}$. そこで今回，下肢急性動脈閉塞症の 再灌流障害における白血球の関与について検討す るために実験を行った。

\section{対象および方法}

\section{1）イヌ急性動脈閉塞症モデルの作製}

体重 15～20 kg の雑種成犬 28 頭を Pentobarbital $(0.5 \mathrm{ml} / \mathrm{kg})$ を用いて静脈麻酔後, 腹部正 中切開で開腹した。まず腎動脈以下の腰動脈およ び下腸間膜動脈を根部にて結禁切離し，さらに腹 部大動脈を腎動脈直下と総腸骨動脈分岐直前の計 2 か所で結禁した。結禁した末梢動脈の拍動消失 を確認した後，閉腹し，イヌ急性動脈閉塞モデル とした。また術中より cephalosporin 系抗生物質 $1 \mathrm{~g}$ を点滴静注し, 術中術後にかけ生理的食塩水 $1000 \mathrm{ml}$ を投与した。麻酔覚醒後は水分のみの経 口摂取を開始した。

2) 再灌流

腹部大動脈結禁 12 時間後に, 両大腿動脈の拍 動の消失, 両後肢の冷感と筋の硬直さらに歩行不 可能なことを確認し，再度 Pentobarbital (0.25 $\mathrm{ml} / \mathrm{kg}$ ）静脈麻酔下に再開腹し，大動脈結禁系を 除去して遮断を解除し，イヌ急性動脈閉塞再灌流 モデルとした。このうち，12 頭をコントロール 群（以下C 群）とした。

実験 1 では，再灌流時に白血球除去フィルター （Sepacell R 500 A ：旭メディカル，日本）を腹 部大動脈に插入し，再灌流直後より 60 分間流入 する血液中の白血球を除去した群（以下F群） を 8 頭作製し，これを C 群と比較検討した。な お，フィルター装着前に Heparine $(0.06 \mathrm{ml} /$ $\mathrm{kg}$ ）を全身投与した。またフィルターは白血球 除去能の劣化を考慮し，20 分ごとに交換して計 3 個使用した（図 1 上).

実験 2 では，再灌流直前に下腸間膜動脈より LTB 4 の拮抗物質 ONO-4057 (3 mg/ $\mathrm{kg})$ を注 入した群（以下 LTB 4 群）を 8 頭作成し，C群 と LTB 4 群の両群間において比較検討した（図 1 下)。

3）測定項目および測定方法

測定項目は，CPK，イヌ Myoglobin，GOTを
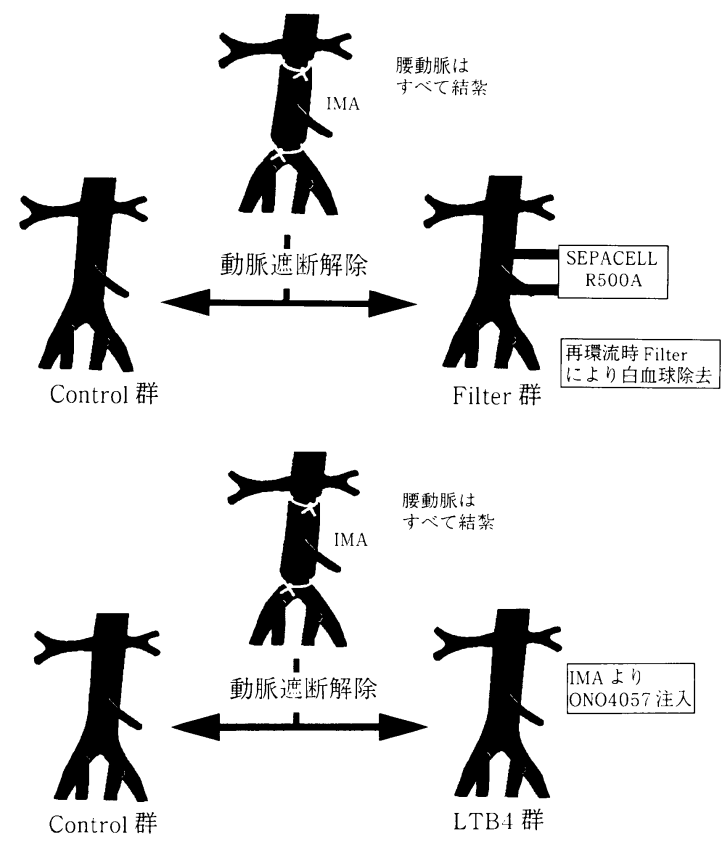

図 1 実験 1 模式図 (上), 実験 2 模式図(下)

測定し，採血は術前，12 時間の遮断解除直前， 再灌流 30 分後, 1 時間後, 3 時間後, 6 時間後, 12 時間後， 24 時間後まで中心静脈より行った。 なお，白血球除去フィルターを用いた実験では， 白血球数の測定と白血球除去効果をみるため，フ イルター前後の白血球数の測定も行った.これら 血液サンプルは採血後直ちに血清に分離し，測定 するまで冷凍保存した。

4）イヌ-Myoglobin の測定

イヌ骨格筋をホモジネートし，同量の蒸留水を 加え一夜放置し，遠心分離器により得た上澄みを Myoglobin 粗液とし，それを $50 \%$ 飽和硫安で塩 析を行った。その遠心分離した上澄みに少量のフ エリシアン化カリを加え，0.02 リン酸緩衝液 PH 6.5 に塩析し, 同条件に平衡化した CM Sephadex C-65 カラムに吸着させ, 同緩衝液で溶出 し, Myoglobin 分画を得た。この Myoglobin 分 画を濃縮し，ゲル濾過を行い精製 Myoglobin を 得た。得られた精製 Myoglobin を家兔に免疫し 抗体を作製した。測定原理としては，抗イヌ Myoglobin 抗体感作ラッテクスと被検検体を測 定用キュベットで混和し凝集させ，抗原抗体反応 の結果生じるラッテクス粒子の分散状態の濁度変 
化として分光光度計で抗原量を算出することによ り測定した。

5) 統計的処理

測定值はすべて平均值土標準偏差で表示した。 また，統計的処理は Welch's $t$-test 法を用いた。 p-value は，0.01 以下を有意とした。

\section{結果}

\section{1. 実験 1}

1）白血球数：中心静脈からの採血つまり全身 血に扔いて再灌流直前まで両群間に有意差を認め なかった. F 群では再灌流 30 分後に $56.8 \pm$
14.4\%，1 時間では 75.5土11.6\%の白血球除去効 果を認めた。フィルター直下の採血においては, 30 分間で $95.9 \pm 2.3 \% ， 1$ 時間では $98.8 \pm 0.8 \%$ の白血球除去効果を認めたＦ群の白血球は再灌 流 12 時間後より徐々に増加傾向を示したが, 両 群間に再灌流後 24 時間まで有意差を認めた（図 2 上)。

2）イヌ Myoglobin：C群では遮断前 40.0土 $20.3 \mathrm{ng} / \mathrm{ml}, 12$ 時間大動脈遮断後 $3,901.3 \pm$ $698.5 \mathrm{ng} / \mathrm{ml}$ であり, 再灌流後より急上昇し, 30 分で $45,893.8 \pm 4,878.7 \mathrm{ng} / \mathrm{ml}$ とピークを示し, その後しだいに減少し，24 時間後には $6,150 \pm$
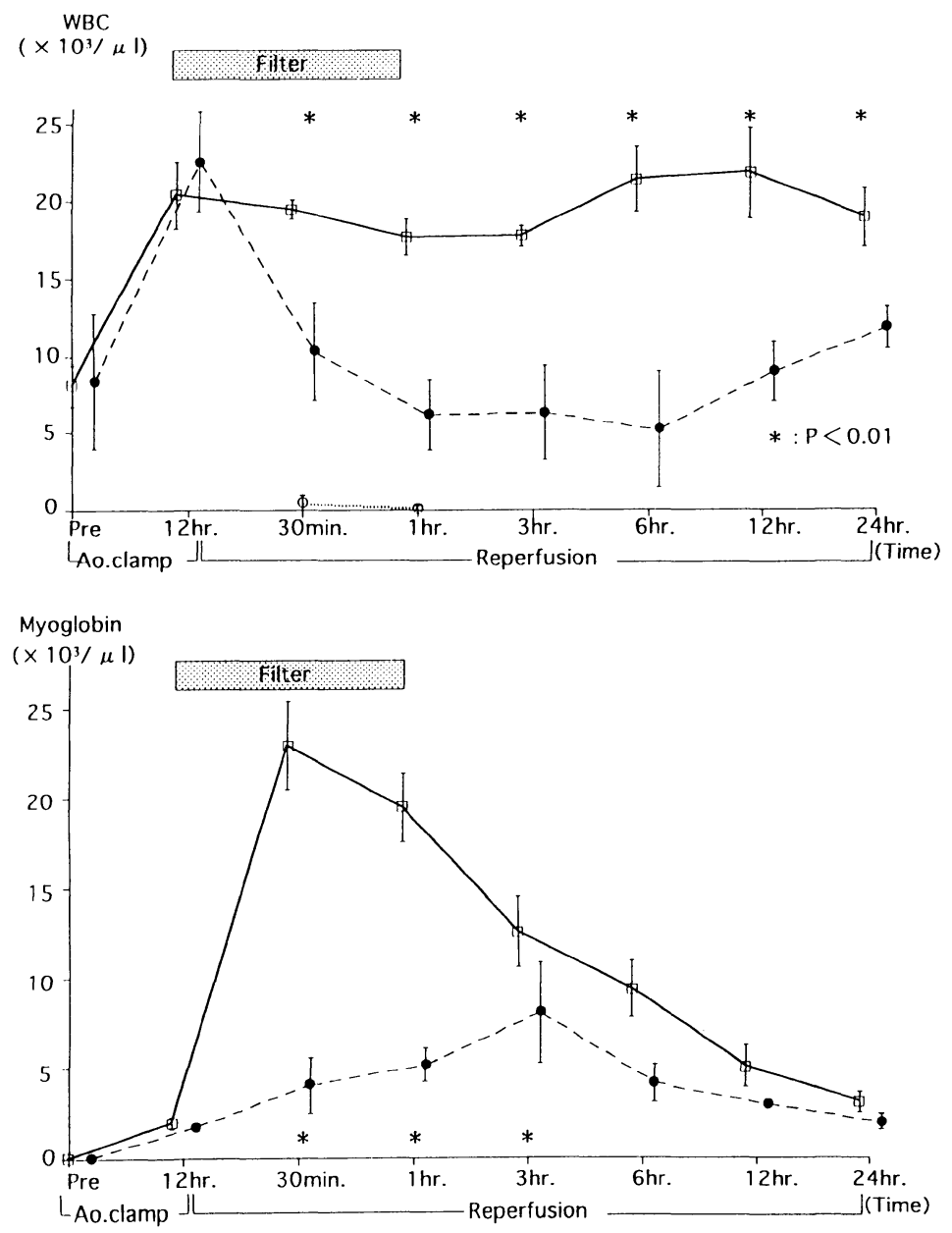

図 $2 \mathrm{C}$ 群と $\mathrm{F}$ 群扔よびフィルター直下採血における白血球数の推移(上), C 群 と F 群における Myoglobin の推移(下)

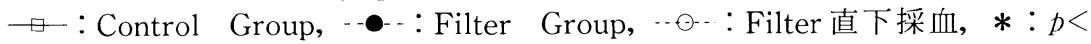
0.01 . 
$1,171 \mathrm{ng} / \mathrm{ml}$ となった。F 群では，再灌流後 6 時 間で $8,315.3 \pm 2,132 \mathrm{ng} / \mathrm{ml}$ とピークを示し，そ の後ゆっくりと減少傾向を認めた．再灌流後 30 分より 24 時間後までのすべての時相において両 群間に有意差を認めた（図 2 下）。

3） CPK：C群では再灌流 3 時間後に 47,569.4 $111,025.9 \mathrm{IU} / l$ とピークを示し，その 後しだいに減少したＦ群ではピークを迎える時 間が遅れ，再灌流後 12 時間で $31,543.3 \pm$ $3,768.9 \mathrm{IU} / l$ まで増加したが，C群のピーク值 $47,569.4 \pm 11,025.9 \mathrm{IU} / l$ に比し，有意に低值と なった。また，再灌流 30 分後より 3 時間後まで
両群間に有意差を認めた (図 3 上).

4）GOT：C群においては再灌流直後より急上 昇し, 再灌流 3 時間後に $1,319 \pm 276 \mathrm{IU} / l$ とピー クを示した。F群では再灌流 24 時間後に $1,244.3 \pm 81.6 \mathrm{IU} / l$ とピークを示し，再灌流後 30 分より 6 時間まで，両群間に有意差を認めた (図 3 下).

\section{2. 実験 2}

1）イヌ Myoglobin：LTB 4 群において, 再灌 流 30 分後に $18,109.6 \pm 1,707.9 \mathrm{ng} / \mathrm{ml}$ とピーク を示したが，再灌流後すべての時相において C 群より低值となり，再灌流 30 分以後の両群間に
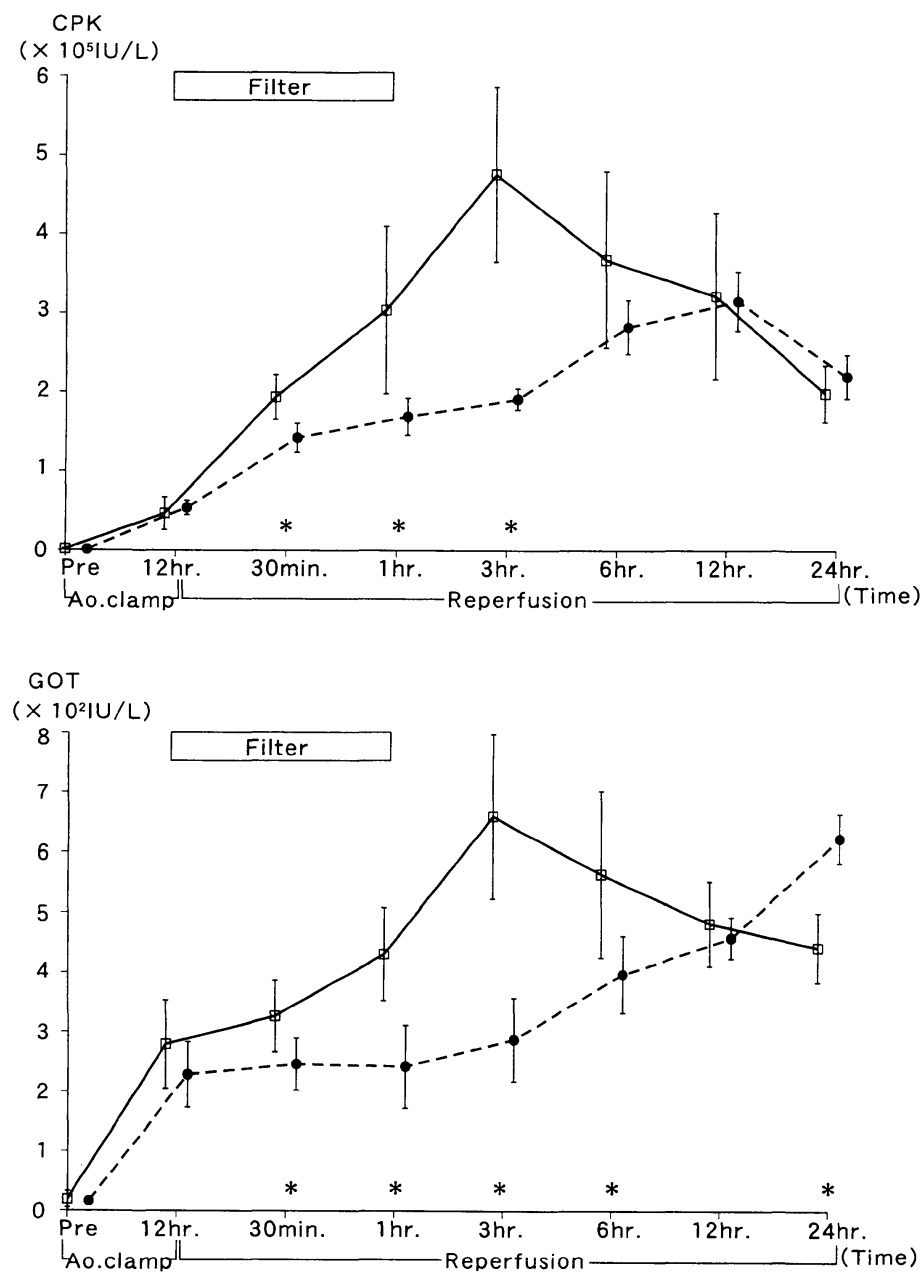

図 $3 \mathrm{C}$ 群と $\mathrm{F}$ 群における $\mathrm{CPK}$ の推移(上)，C群と $\mathrm{F}$ 群における GOT の推移 (下) 

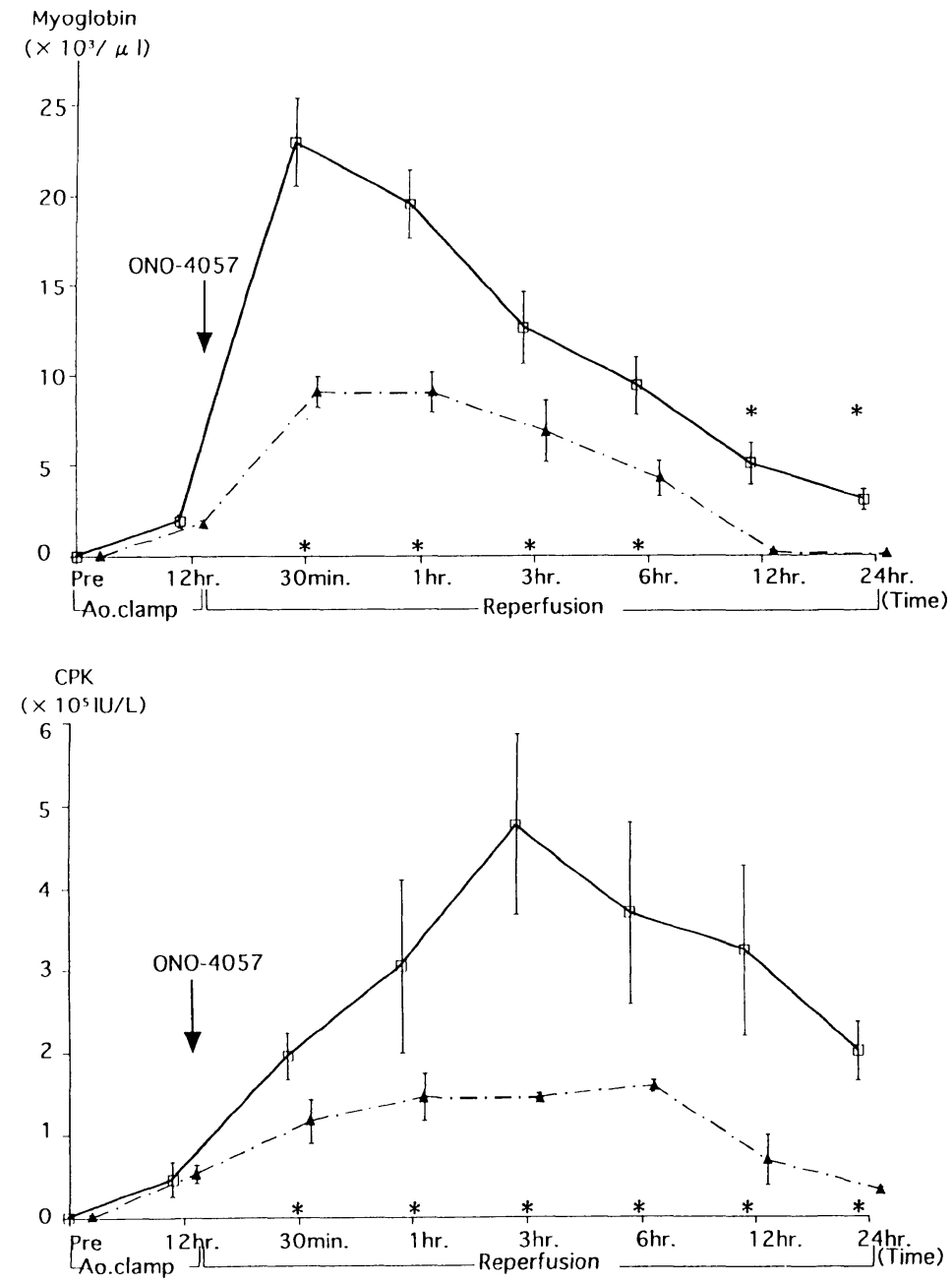

図 4 C 群とLTB 4 群における Myoglobinの推移(上), C 群とLTB 4 群におけ る CPK の推移(下)

$\rightarrow-$ : Control Group, $\bullet \bullet \cdot:$ LTB4 Group, $*: p<0.01$.

有意差を認めた (図 4 上).

2) CPK：LTB 4 群に扔いて，再灌流 6 時間で $15,700 \pm 777.8 \mathrm{IU} / l$ とピークを示し，再灌流 30 分以後に扔いて両群間に有意差を認めた（図 4 下).

3）GOT：LTB 4 群において，再灌流 3 時間 で $567 \pm 101.3 \mathrm{IU} / l$ とピークを示し，6時間後 $511.8 \pm 65.7 \mathrm{IU} / l, 12$ 時間後 $442.5 \pm 54.4 \mathrm{IU} / l$, 24 時間後 $284 \pm 33.9 \mathrm{IU} / l$ と減少した。再灌流 30 分以後に扔いて両群間に有意差を認めた（図 5 上).

\section{考察}

急性動脈閉塞症に対する治療の原則は早期の血 栓塞栓除去術による血行再建であり, 大部分の症 例では局所的にも全身的にも障害を残さず回復す るが，その一方では下肢虚血再灌流後に Myonephropathic-metabolic syndrome（以下 MNMS）に代表される多臟器障害を合併する症 例もあり ${ }^{1 \sim 3)}$, 一度本症を併発すれば致命率が高 く，いまだに解決されずに残る合併症の一つであ る.

以前より教室では，MNMS における病態の解 

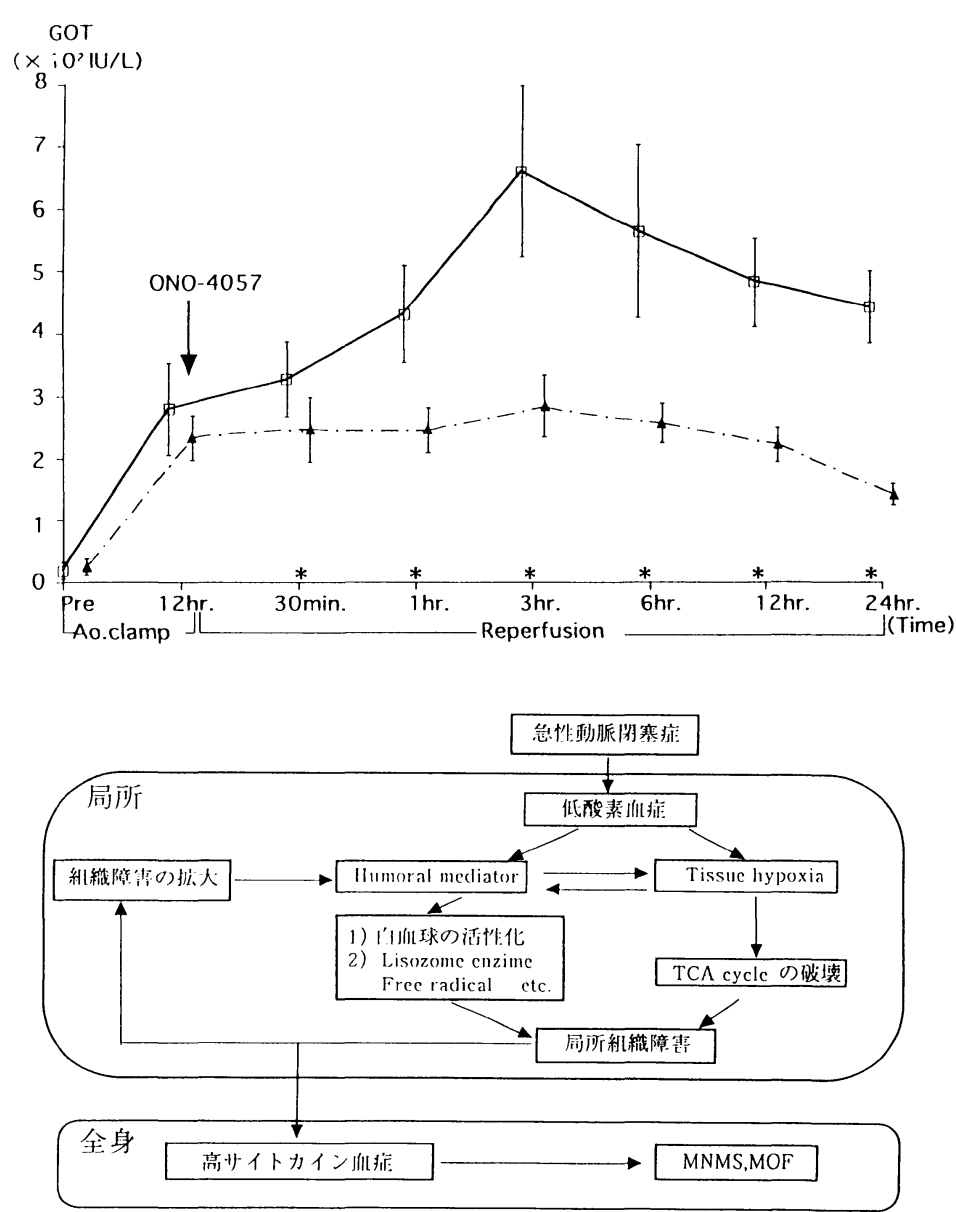

図 5 C 群とLTB 4 群における GOT の推移(上)

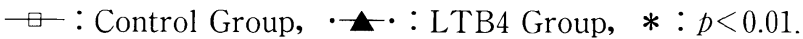

下肢急性動脈閉塞症における再灌流障害の理論的背景(下)

明や発生予防と，その治療方法を確立すべく，研 究を重㸚てきた年7,15) が, 当初, 従来より MNMS の原因物質とされていた Myoglobin や その他の原因物質としての未知毒を除去する目的 で Hemofilterを応用し，実験的 ${ }^{15)} に も$ 臨床的5) にもその有効性を証明してきた。さらに MNMS の病態に free radical の関与していることに注目 $し$, ascorbic acidやFOY 9 scavenger 効果 ${ }^{4}$

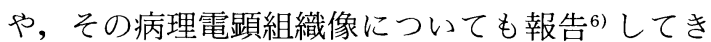
た。しかしこれらだけでMNMSの病態のすべ てを説明することは不可能であり，とくに下肢局 所に発生した組織障害が全身的組織障害へと進展 し, MNMS を呈する病態については未だ不明で あり，これまでの知見を臨床に十分反映させるま
でには至らなかった。最近になり，心臓や肝蔵， 肺を始めとした他分野での虚血再灌流障害の研究 が進むにつれ，free radical 以外にもさまざまな humoral mediator の存在が明らかになりつつあ り，再灌流障害とはそれらさまざまな humoral mediator が関与して引き起こされる全身的炎症 性疾患としてとらえられるようになってきてい る。つまり，局所にさまざまな侵襲が加えられる と白血球や血管内皮を始めとした細胞から humoral mediator が産生されるが，侵襲の程度 が強度である場合には humoral mediator が大量 に産生され，侵襲を受けた局所のみならず血中に も流出し, 高サイトカイン血症の状態を呈 し11,12)，それが誘因となって全身的広範囲な臓器 
障害を引き起こしてくるのである。すなわち，こ の状態が systemic inflammatory response syndrome（全身性炎症性反応症候群，以下 SIRS） であり, $\mathrm{MOF}^{11} や \mathrm{MODS}^{16)} へ の$ 準備状態であ る17)とされており, 著者はMNMSもこの MOF, MODS と同様の機序で引き起こされるも のと考えている.

実際に，フィルターにより白血球を除去した実 験 ${ }^{18,19)}$ ，あるいは白血球に対する抗体 ${ }^{20)}$ や白血球 の機能を低下させる薬剤を投与する実験 ${ }^{21 ~ 23) に ~}$ おいて, 白血球の抑制により再灌流障害が軽減さ れるという報告が数多くなされている。また再灌 流後の障害組織には白血球が集積しているとした 報告 ${ }^{22)}$ や，下肢虚血再灌流後の血中白血球の遊 走能8), 貧食能9), 活性酸素産生能(10)の六進を証 明し，これら白血球の活性化が遠隔臓器障害と密 接な関係をもつとする報告 ${ }^{8 \sim 10)}$ は，いずれも再灌 流障害における白血球の関与を示唆している。こ れら白血球の活性化を引き起こす humoral mediatorにはLTB 4, Thromboxane $\mathrm{A}_{2}$ (以下 $\mathrm{TXA}_{2}$ ) やplatelet activating factor (以下 PAF)，活性化補体第 5 成分 (以下 $\mathrm{C} 5 \mathrm{a}$ ), Interleukin-1（以下IL-1）を始めとした Interleukin-6（以下 IL-6), Interleukin-8（以下 IL-8), tumor necrosis factor (以下 TNF) 等の 各種サイトカインなどが想定されている ${ }^{10,24)}$ が, このなかでLTB 4 は極めて強力な白血球活性化 作用を有し, 白血球の遊走, 粘着, 凝集を惹起 し, 貧食, 活性酸素の産生, 放出, ライソソーム 酵素の放出を促進するとされている ${ }^{25)}$. LTB 4 の白血球遊走，粘着，凝集の惹起作用は細菌の産 生する白血球遊走惹起物質であるホルミルペプチ ド，C $5 \mathrm{a}, \mathrm{PAF}$ などのそれと同等以上の強さを 示すとされ，Goldman ら ${ }^{26)}$ は，下肢虚血再灌流 時には血液中の LTB 4 濃度が上昇しており, 再 灌流時の活性酸素の消去または白血球の除去が血 液中の LTB 4 の上昇を抑え, その結果白血球の 浸潤も抑制できたと報告しており，活性酸素の刺 激で白血球が LTB 4 を産生する過程において下 肢虚血再灌流時の遠隔藏器障害に抢ける白血球浸 潤を説明している。また Welbourn ら ${ }^{27)}$ は下肢 虚血再灌流時には気管支肺胞洗浄液 (Broncho- alveolar lavage fluid, BALF) 中の LTB 4 濃度 が上昇したと報告している。

そこで本研究においては下肢虚血再灌流障害に おける白血球の関与を証明するため. 白血球除去 フィルターと LTB 4 拮抗物質を用いた実験を行 った。今回用いた ONO-4057 は，LTB 4 の受容 体拮抗剤として小野薬品工業株式会社によって開 発された化合物であり, LTB 4 惹起の白血球の 遊走，凝集促進などの作用を抑制することが in vitro の実験でも明らかとなっている ${ }^{28)}$. また in vivo の実験でも静脈内投与にて LTB 4 惹起白血 球減少に対する作用や，経口投与にて LTB 4 惹 起白血球浸潤に対する作用が起きることが報告さ れている ${ }^{28)}$.

今回のイヌ急性動脈閉塞症モデルにおける実験 では，本症のなかで大きな役割を果たしていると 思われる白血球に着目し，その影響を 2 種類の方 法で除去することにより，組織障害軽減の可能性 を検討した。C群では下肢虚血再灌流後, Myoglobin, CPK, GOT の各測定項目は上昇傾向をみ せたが，白血球除去フィルターを用いた F 群に おいては再灌流後に若干の上昇傾向を示すもの の, C 群に比へ極めて低值を示し，組織障害を抑 制したものと思われた。しかし，白血球除去フィ ルターによる白血球除去効果は, 1 時間のフィル ター使用により再灌流後 6 時間ぐらいまでは白血 球数を低值に抑えることができたものの，その後 網内系のいわゆる marginal pool からの白血球の 流出が起こるために，フィルター除去後にしだい に組織障害が進行していったものと推測された. またLTB 4 拮抗物質投与においては, 白血球除 去フィルターとは異なり, 白血球数の絶対值にか かわらず，好中球の活性化抢よび遊走を抑制する ことによるものであり，再灌流後より長時間にわ たり組織障害の軽減が可能であった，白血球除去 効果と LTB 4 受容体の拮抗効果が再灌流障害に おいてどちらが有用であったのかは, 白血球除去 フィルターの使用時間や LTB 4 拮抗薬の薬剤投 与量にも大きく依存するため今回の実験結果から だけでは，結論できないと思われた。

著者は下肢虚血再灌流障害の病態を以下のごと く考えている.すなわち，動脈の閉塞により虚血 
に陥った局所では，酸素供給量の減少により酸化 的リン酸化（いわゆる好気的解糖）によるエネル ギー産生が不可能となり嫌気的解糖が進み，その 結果乳酸が蓄積しアシドーシスとなり，さらに虚 血が続けば生体膜の維持が困難となり, 細胞崩 壊，組織障害が引き起こされてくる。またその一 方で起炎刺激の除去，障害を受けた組織の修復と いう一連の防御反応として，さまざまな humoral mediator の産生と白血球の活性化がおこり, この白血球は，接着分子を介して，障害部位の血 管内皮細胞に接着凝集 ${ }^{29)}$ され，さらに血管内皮 細胞より障害組織へ透過浸潤し，局所の細胞障 害，組織障害をさらに増大することになる。ま た，その過程に扔いて産生された $\mathrm{O}_{2}$ フリーラジ カル4 40 やプロテアーゼなどもこれら障害をさら に助長し, 局所組織破壊が連鎖反応的に増幅され ていくこととなる。また，これら局所で産生され た humoral mediator は，全身に灌流され，その 結果, 全身的な高サイトカイン血症となり，その サイトカインが心，肺，腎等，下肢と離れた部位 で虚血下肢と同様の機序で組織障害を引き起こ し，ついにはMNMSゃMOFを発症させてくる と考えている (図 5 下)。つまり下肢局所におい て引き起こされた組織障害が各種サイトカインに より全身へ運ばれ，全身の各臟器に同様の組織障 害を引き起こし，その障害の総和として MNMS が形成され，この高サイトカイン血症，さまざま なサイトカインネットワークこそが，MNMS 発 症の key point と考えた。

今回の実験結果は，これら病態において白血球 の関与を除去した際の組織障害を検討したもので あるが，いずれの方法においても組織障害の指標 である CPK, Myoglobin, GOT が著明に軽減して 抢り，白血球の担う役割が非常に大きいものであ ることを示唆していると考えられた。

\section{結語}

1）イヌ下肢急性動脈閉塞モデルを用い，本症 の再灌流障害の病態生理について検討した。

2）実験 1 : 白血球除去フィルターを用いた虚 血下肢への白血球の再灌流を減少させる実験にお いて，急性動脈閉塞症の組織障害を軽減すること
ができた。

3）実験 2：白血球遊走阻害剤であるLTB 4 拮 抗剤（ONO-4057）を投与することでも急性動脈 閉塞症の組織障害を軽減することができた。

4）以上の結果より，本症の組織障害増大には 白血球が強く関与しているものと考えられ，さら にこの白血球の関与は MNMSの病態解明の鍵 になるものと推察された。

稿を終えるに臨み，ご指導，ご校閲を賜りまし た恩師瀬在幸安教授に深く感謝の意を表するとと もに，ご指導，ご助言打よび研究において多大な ご協力をいただきました教室の諸兄に心から厚く 御礼申し上げます。

\section{文献}

1) Haimovici, H.: Metabolic complications of acute arterial occlusions conditions: Role of free radicals (myonephrotic metabolic syndrome). In: Haimovici's Vascular Surgery, eds. by Haimovici, H., Depalma, R. G., Ernst, C. D. et al., pp. $386^{-408}$, Appleton \& Lange, Norwalk, 1989 .

2) Anner, H., Kaufman, R. P., Kobzik, L. et al. : Pulmonary hypertension and leukosequestration after lower torso ischemia. Ann. Surg. 206 : 642-648, 1987.

3) Welbourn, R., Goldman, G., O'riordain, M. et al. : Role of tumor necrosis as factor as mediator of lung injury following lower torso ischemia. J. Appl. Physiol. 70 : 2645-2649, 1991.

4) 渡井建男：MNMSに対する oxygen radical scavenger の効果に関する研究一とくに SOD 活 性と組織逸脱酵素に対寸る実験的検討。日心外会 誌 20：5-10, 1990.

5）一和多雅雄：MNMSに対する新しい予防と治療 方法ープラズマフィルトレーションの応用一. 日 外会誌 89：1114-1121, 1988.

6）四万村三恵：急性動脈閉塞症における腎臓およ び動脈の光顕的, 電顕的所見. 日心外会誌 $21: 24$ 34, 1992.

7）萩原秀男, 根岸七雄, 瀬在幸安ほか：MNMS の病 態生理と治療の研究. 日心外会誌 17：480-485, 1988.

8) Summers, S. T., Wyatt, L. E. and Freischlag, J. : Persistant neutrophil (PML) activation $24 \mathrm{hr}$ after ischemia and reperfusion. Ann. Vasc. Surg. 56 : 130-133, 1994.

9) Freischlag, J.A. and Hanna, D.: Neutrophil 
(PML) phagocytosis and chemotaxis after reperfusion injury. J. Surg. Res. 52: 152-156, 1992.

10) Cambria, R. A., Anderson, R. J., Dikdan, G. et al.: Leukocyte activation in ischemiareperfusion of skeletal muscle. J. Surg. Res. 51: 13-17, 1991.

11) Deitch, E. A.: Multiple organ failure. Ann. Surg. 216 : 117-134, 1992.

12) Cavillon, J., Munoz, C., Fitting, C. et al. : Circulating cytokine: the tip of the iceberg?. Circ. Shock 38: 145-152, 1992.

13) Ascer, E., Mohan, C., Gennaro, M. et al. : Interleukin-1 and thromboxane release after skeletal muscle ischemia and reperfusion. Ann. Vasc. Surg. 6 : 69-73, 1992.

14) Sekido, N., Mukaida, N., Harada, A. et al.: Prevention of lung injury in rabbits by a monoclonal antibody against interleukin-8. Nature 365 : 654-657, 1993.

15）新野成隆：開心術後腎障害の予防に関する実験 的検討一人工心肺中の血漿遊離へモグロビン除 去について一. 胸部外科 35(1): 26-34, 1987.

16) 斎藤英昭: 臓器不全の発生機序とそのメディエ ター. Surgery Frontier 1(1): 21-28, 1994.

17) Members of the American College of Chest Physicians/Society of Critical Care Medicine Consensus Conference Committee: Difinitions for sepsis and organ failure and guidelines for the use of innovative therapies in sepsis. Crit. Care Med. 20: 864-874, 1992.

18) Westlin, W. and Mullane, K. M. : Alleviation of myocardial stunning by leukocyte and platelet depletion. Circulation 80 : 1828-1836, 1989.

19) Kutumi, Y., Misawa, T., Tada, H. et al. : Effect of leukocyte-platelet removal filter on ischemia induced reperfusion injury. ASAIO Transactions 36 : M723-M726, 1990.

20) Romson, J. L., Hook, B. G., Kunkel, S. L. et al. : Reduction of the extent of ischemic myocardial injury by neutrophil depletion in the dog. Circulation 67: 1016-1023, 1983.

21) Simpson, O. J., Mitsos, S. E., Ventura, A. et al. : Proctacyclin protects ischemic reperfused myocardium in the dog by inhibition of neutrophil activation. Am. Heart J. 113: 129-137, 1987.

22) Simpson, P. J., Mickelson, J., Fantone, J. C. et al.: Iloprost inhibits neutrophil function in vitro and limits experimental infarct size in canine heart. Circ. Res. 60 : 666-673, 1987.

23) Simpson, P. J., Mickelson, J., Fantone, J. C. et al. : Reduction of experimental canine myocardial infarct size with prostaglandin E1: Inhibition of neutrophil migration and activation. J. Pharmacol. Exp. Ther. 244 : 619-624, 1988.

24) Paterson, I. S., Smith, F. C. T., Tsang, G. M. K. et al.: Reperfusion plasma contains a neutrophil activator. Ann. Vasc. Surg. 7: 68-75, 1993.

25）柴忠明, 池田正視, 原彰夫ほか：Leukotrienes. 救急医学 13(8)：937-944, 1989.

26) Goldman, G., Welbourn, R., Klausner, J. M. et al.: Oxygen free radicals are required for ischemia-induced leukotrien B4 synthesis and diapedisis. Surgery 111: 287-293, 1992.

27) Welbourn, C. R. B., Goldman, G., Paterson, I. S. et al.: Neutrophil elastase and oxygen radicals: Synergism in lung injury after hindlimb ischemia, Am. J. Physiol. 260 : H1852-H1856, 1991.

28) Kishiyama, K., Tateishi, N., Maruyama, T. et al. : ONO-4057, novel, orally active leukotrien B4 antagonist: Effects on LTB4-induced neutrophil functions. Prostaglandins 44 : 261275, 1992.

29) Harlan, J. M.: Leukocyte-endothelial interactions. Blood 65: 513-525, 1985.

30) Granger, D. N., Rutili, G. and McCord, J. M. : Superoxide radicals in feline intestinal ischemia. Gastroenterology 81: 22-29, 1981. 